\title{
THE SNAIL, ICON/BLAZON OF SAINT ANTHIM THE IBERIAN
}

\author{
Mihaela PALADE*
}

\begin{abstract}
Buffon's remark about personal expression, i.e. The style is the man himself /Le style est l'homme même has long stepped out of the literary field and come to define anyone's personality, in particular, the way of expressing themselves, their behaviour, their manner of dressing or eating. In addition to all these, certain people, usually those who enjoy a special political, social, cultural and/or religious status have adopted a particular emblem, a blazon meant to represent them, which appears on most of their personal belongings.

Their choice is not accidental, but rather based on certain complex considerations, whose reasons may be known, overtly confessedor, on the contrary, only presumed; in the latter case, the symbolic decyphering plays a major role. More often than not, the blazon was seen not only as an emblem of the person who adopted it, but also as his own mirror, which could reveal certain hidden psychological facets of its holder.

The present study aims at highlighting certain aspects of the snail, considered to be not only the personal blazon of the Metropolitan Anthim the Iberian, but also his icon, his manner of self-representation, humble but very resolute as well.
\end{abstract}

Keywords: Anthim the Iberian, snail, tentacles, arms, prayer, humility, blazon.

\section{Saint Anthim the Iberian}

Historically knwon as "Metropolitan Anthim the Iberian", he reached the Romanian Principality after he had spent a large part of his life in hardship and adversity, in a medium hostile to the Orthodox faith

PhD, Professor, University of Bucureşti, Faculty of Orthodox Theology "Patriarch Justinian" (Department of Practical Theology, Systematic Theology and Sacred Art). 
and genuine values. His presence in the Principality of Wallachia is mentioned for the first time in 1691, which made the historians surmise that he could have come here her between 1688 and 1689-1690 ${ }^{1}$.

In his works, the metropolitan himself had indicated his Georgian origin, calling himself Anthim the Iberian, Anthim of Georgian breed or Anthim the Hieromonk, printer from Iberia ${ }^{2}$. After he had settled in Ungro-Wallachia, he showed a real talent in the art of books, learning the skills of printing from Mitrofan of Buzau and quickly becoming a "master in this art"'3.

His end was as harsh as the beginning of his life. Caught up in a conflict with the new Phanariote prince, Nicholas Mavrocordat, the Turks, the Austrians and the Cantacuzinos, he was imprisoned at court and forced by threats to resign his metropolitanate, in writing. He was afterward sentenced to life imprisonement at the monastery of Mount Sinai and then dispatched in full night, under the supervision of a few Turks. Once they reached Galipoli, near the Dulcia River which crosses Adrianopol, he "was killed and thrown into the river"4.

His ample works have been researched under several aspects, and his achievements as "a printer, translator, writer, architect, drawer, miniaturist, librarian and archiver have been fully acknowlegded; however, his endeavours in the field of heraldry are less known" ${ }^{5}$ and they may offer certain surprises as we will see soon.

\section{Heraldic Symbols and Ecclesiastic Emblems in Saint Anthim the}

${ }^{1}$ Gabriel ŞTREMPEL, "Introducere", in Gabriel ŞTREMPEL (Critic edition and introductory study) Antim Ivireanul, Opere, Bucureşti, Minerva, 1972, p. VII.

2 I. BIANU / Nerva Hodoș, Bibliografia românească veche, tomul I (1508-1716), Bucuresci, Stabilimentul Grafic V C Socec, 1903, p. 324-326; Nicolae ŞERBĂNESCU, “Antim Ivireanul tipograf”, in Biserica Ortodoxă Română (hereinafter: BOR), no. 89/1956, p. 701; G. Ştrempel, Introducere, p. VI.

${ }^{3}$ Nicolae IoRGA, Istoria literaturii româneşti, Vol. II, Bucureşti, Editura librăriei Pavel Suru, 1926, p. 465.

4 Anton-Maria Del ChIARo Fiorentino, Revolutiile Valahiei (according to the re-edited text published by N. Iorga), in Romanian by de S. Cris-Cristian, Iaşi, Viaţa Românească, 1929 , p. 54 , http://www.cimec.ro/carte/delchiaro/RevolutiileValahiei.pdf.

${ }^{5}$ Maria Dogaru, “Antim Ivireanul et l'art héraldique de la Valachie”, in Revue d'études sud-est européenes, no. 2/1976, p. 317. 


\section{Iberian's Time}

It is worth mentioning that, starting from the 17th century in the Principalities of Wallachia and Moldavia heraldic representations began to come out, especially in printing ${ }^{6}$.

Saint Anthim the Iberian's printed works are not richly adorned, but they all feature the Principality of Wallachia's coat of arms overleaf the title page. An analysis of the heraldic structure reveals several versions, all of them featuring an eagle holding a cross in its beak; it is obvious that all these versions belonged to the Pricipality of Wallachia in Constantin Brancoveanu's time whereas the works printed during Stephen Cantacuzino's time bear his heraldic symbols ${ }^{7}$.

In two documents, issued in the space of a few years (one on 1 May 1709 and the scroll of 25 March 1714) Saint Anthim used the big metropolitan signet (57 $\mathrm{mm}$ in diametre) featuring the Saint Emperors Constantin and Helena holding the Cross, with city walls in the background, encircled by the text: By God's Mercy, Anthim, Metropolitan of Ungro-Wallachia ${ }^{8}$. But all these symbols are radically different from what was to appear in the documents issued on the occasion of the foundation of his monastery in Bucharest; the monastery will bear his name, Anthim, and not its saint patrons' as it is customary.

\section{Documents issued on the foundation of Antim Monastery}

Following a divine revelation, on the day of Saint Martyr Agatha's feast (5 February), in the spring of 1713, the Metropolitan Anthim began the works of erecting the monastery. On the open porch, there is a portal which displays an unusual floral decoration, crowned on the upper side by a floral wreath with free rims, unframed. On the bottom side one can see a circular medallion where in a laurel-like wreath stands out an absolutely special shape which, from the distance looks similar to the surrounding curly stalks. In fact, on the bottom side of the votive

${ }^{6}$ Dan CERnOvodeanu, "Heraldica bisericească în Ţările Române”, in BOR, no. 7-8/1975, p. 962.

${ }^{7}$ M. Dogaru, “Antim Ivireanul et l'art...”, p. 317-318.

8 Aurelian SacerdoțEAnU, "Sigiliile Mitropolitului Antim Ivireanul", in Mitropolia Olteniei, no. 9-10/1966, p. 838. 
inscription right over the entrance, there's a snailkeeping vigil in a rather unusual stance (Fig. 1). It is not, however, the only place where the snail appears as it can also be seen in the documents issued by the monastery's founder.

Among the manuscripts owned by the Romanian Academy, a very important one is number 3342, The Settlement of the Holy Monastery Anthim, written and illustrated on 23 April 1713, "a unique piece of our old culture through its content and the art of miniature" .

On f. $4^{\mathrm{v}}$ one can see the Teachings for the Settlement of the Venerable Monastery of All Saints ${ }^{10}$, and overleaf its front page, "in a cartouche with lateral indentations there's a snail set in pale topped by a six-rayed star" 11 . At the end of the works in 1715, the Metropolitan reaffirmed his regulation by the Bishopric Bill of Saint Anthim, Metropolitan of Ungro-Wallachia, issued on 25 July $1715^{12}$.

As regards the choice of a snail as a Metropolitan's symbol, it represents an extremely rare occurence in Romanian heraldry. In establishing the snail as the Metropolitan's blazon, we've started by cautious suppositions and come to firm statements.

\section{Saint Anthim the Iberian's Personal Blazon}

In a study published in 1885 , Ghenadie Craioveanu mentioned that in all the carvings made by the Metropolitan Anthim one might notice "melcul (snail) sau culbecul" at every step, which made him think that the snail represented a "kind of emblem" for Anthim"13. In 1973 Gabriel Strempel considered the snail as "the personal blazon of the Metropolitan Anthim"14, and in 1975 Dan Cernovodeanu climed that the image in the

9 Gabriel ŞTREMPEL, Catalogul manuscriselor româneşti, vol. III, B.A.R. 3101-4413, Bucureşti, Editura Ştiinţifică şi Enciclopedică, 1987, p. 7.

${ }^{10}$ Antim IVIREANUL, Opere, p. 325-346; G. Ştrempel, Catalogul manuscriselor româneşti, p. 93.

${ }^{11}$ Dan CERnovodeanu, Ştiinţa şi arta heraldică în România, Bucureşti, Editura ştiinţifică şi enciclopedică, 1977, p. 179.

12 Aurelian SACERdoȚEANU, “Antim Ivireanul, arhivist, bibliotecar şi topograf”, in Glasul Bisericii, no. 9-10/1963, p. 882.

13 Ghenadie Craiovenu, "Testamentul Mitropolitului Antim Iverenu", in BOR, no. 3/1885, p. 229.

${ }^{14}$ Antim IVIREAnul, Opere, p. 454. 
manuscript issued on 20 July $1715^{15}$ represented Metropolitan Anthim' emblem $^{16}$ or the Metropolitan's personal emblem ${ }^{17}$. A year later, Maria Dogaru assumed that "the Metropolitan's personal blazon is a snail in pale"18 (Fig. 2).

One may notice that at Antim Monastery, "over the doors, under the votive inscription there is the "Gherb" - Anthim's emblem - symbol of the tombs from which on the Judgment Day the dead will come out or, rather of the monk, who must guard the entrance to the monastery church" 19 . To sum up, the snail is deemed to be the blazon of Metropolitan Anthim the Iberian, but the choice of a snail is not as uncommon as the manner of its representation.

\section{Peculiar Architectural Symbolic Features of Saint Anthim the Iberian's Snail}

Those who described the snail saw it standing, but the correct phrasing according to the heraldic jargon is "in pale" 20 : in a cartouche with lateral indentions the personal emblem of the high prelate shows up, namely a snail set in pale topped by a six-rayed star"21. In the compositon of his coat of arms, Saint Anthim took over elements of the snail's anatomy, reconfiguring them in a synthetic-cubist pattern, giving it a shape that transcends our world.

The snail combines two opposite substances, a soft, feeble, vulnerable one (see the Latin name for snail molluscusi, from mollis soft, mushy) and a strong, hard one able to cope with attacks. Saint Anthim turned the feeble, viscous nature which brought out readings with negative connotations, into a steady, resolute one, firmly oriented towards the sky, in a vertical line meant to reach heaven.Thus, the roles were

15 In the custody of Romanian Academy, Mss. orig. rom., nr. inv. 3342.

16 Dan Cernovodeanu, "Heraldica bisericească in Ţările Romane", in $B O R$, no. 78/1975, p. 963.

${ }^{17}$ D. CeRnovodeanu, Ştiinţa şi arta heraldică, p. 179.

${ }^{18}$ M. Dogaru, “Antim Ivireanul et l'art”, p. 320.

${ }^{19}$ Antim IVIREANUL, Opere, p. 432-433.

${ }^{20}$ The pale is a broad vertical band down the centre of the shield. Paly consists of an even number of vertical stripes, http://armorial.library.utoronto.ca/sites/default/Briefheraldic-guide.doc.pdf (Accessed April 1, 2017).

${ }^{21}$ D. Cernovodeanu, Ştiinţa şi arta heraldică , p. 179. 
changed: the shell, the home, the shelter became a bizarre support of the unstable, vulnerable part, which could not maintain it anymore, as it was leaning with its convex part on the ground. Thus, a convex curve which touched the ground at only one point and which at first sight might appear as an unstable foundation (Fig. 3).

Saint Anthim's snail has been set free from its slavery condition of being glued to the earthly and wordly matters, and urged to tend towards the heavenly, spiritual matters. He left its initial position which lent it stability on a gravitational earthly plane choosing instead a position of unstable balance, in a verticality which no longer leans on the ground, but anchors somewhere in the sky, identifying itself with the vertical arm of the Cross. The soft viscous changing body, useful for the snail's advancement becomes a skyward ladder, and the shell carried to and fro, gears its cavity towards the same spiritual space.

Thus Saint Anthim's snail no longer obeys the earthly gravitational force, the rules of our world, but tends toward the sky to a long-awaited and well-deserved rest. There is no imbalance as well, since it is not the shell which supports the mollusc, but it is the latter that carries the shell/home upward on a vertical ladder of virtues. It is this particular manner of representing the snail on Saint Anthim's blazon that makes it special, turning it into a unique symbol.

Even if the snail appears in other paintings too, its posture copycats the natural, zoological one. For instance, in the Church of Sinaia Monastery (presumably painted by Parvu Mutu, Cantacuzinos and Brancoveanu's court painter) there's a snail in The Last Judgment in The Ressurection of the Dead scene (Western wall of the porch, on the right side of the church door $)^{22}$ which, however, follows the horizontal ground line.

As far as other coats of arms are concerned, the snail is not altogether ignored, but in comparison to other animals it appears rather seldom. For this reason, in encyclopedias of heraldics it is relegated to a minor place, if present, which made me search for the needed information

22 Cătălina Velculescu, Ileana STĂNCUlEscu, “Animale între numere şi flori”, in Maria Magdalena Székely (ed.), Lumea animalelor, realităţi, reprezentări, simboluri, Iaşi, Editura Universităţii “Alexandru Ioan Cuza”, 2012, p. 366, note 40. 
in Wikipedia and other sources ${ }^{23}$ (Fig. 4). Regardless of the scientific scarcity of the data, one thing is for sure, i.e. in European heraldry the snail is always represented in the posture of a shuffling mollusc.

Unlike Saint Anthim's snail and despite certain highly suggestive stylized representations, the snail remains a creature dependent on the ground or on the object along which it shuffles. When it appears in a vertical stance, such as in Albrecht Dürer's (1471-1528) engraving from 1515 , it seems to be this way because it advances upward on a vertical support, using its viscous body, with no reference to a search for verticality.

In Saint Anthim the Iberian's case, if we coroborate the ecclesiastic emblems and those of Saint Constantine and Helena's, we may notice that the Metropolitan's blazon featuring a snail in pale accompanied by the bishop's insignia was only made up in the last years of his life, while he was working on the construction of the eponym monastery ${ }^{24}$. Under such circumstances, a natural question arises: which were the reasons for the Metropolitan's decision to choose a snail for his blazon?

\section{Reasons for choosing the snail}

Usually, in the case of printing, at the basis of an engraving with the country heraldic symbols lies their lyrical description ${ }^{25}$, so one reason for choosing the snail may be found in the four lines which accompany the Metropolitan's blazon from the Settlement:

May every creature, as the prophet says,

Praise the Lord in every place.

The snail, too, lifts his horns up high,

Teaching us all to give glory to Him.

("Toată suflarea, zice prorocul,

Cânte pre Domnul peste tot locul.

Şi melciul încă coarne înalţă,

Ca să-L lăudăm, pre toţi ne-nvaţă" $)^{26}$.

${ }^{23}$ Hunting for snails snails in art, https://huntingforsnails.wordpress.com/ category/ heraldry/;

${ }^{24}$ M. Dogaru, "Antim Ivireanul et l'art", p. 320.

${ }^{25}$ Ibidem, p. 318.

${ }^{26}$ Antim IviREANUL, Opere, p. 454. 
Thus, right under the blueprint of the church he intended to build, there is a drawing "made by the founder's hand" representing a snail read as a symbol of humbleness - which extends its tentacle to feel the sun light and warmth, just like the arms of a praying person ${ }^{27}$.

At first, the snail's long tentacles have been associated with those of a urus, an animal which once inhabited our forests. In certain areas of our country, "little urus" is a term used to designate a snail, as it appears in a children's song ${ }^{28}$. Therefore, the snail's tentacles stretched out as in prayer, represented a strong argument for its selection from the wealthy traditional Byzantine bestiary so widespread during Brancoveanu's reign, a period in which the decorative vocabulary, already rich in floral elements, got diversified by receiving also zoomorphic and antropomorphic ones.

\section{The Snail, Icon/Blazon of Saint Anthim the Iberian}

On the front page of the bishop's document, within the medallions around the church all sort of living creatures are represented, making up the Metropolitan's name, AN $\Theta I M O \Sigma$, as an acrostic, in which each letter is accompanied by one of them: A, an eagle (aetoj) taking its flight / $\mathrm{N}$, a bat (nucteri,da) in flight / $\Theta$, a jackal (qw,j) / I, a bird (ie,rax) walking / $\mathrm{M}$, a bee (me,lissa) in flight / $\mathrm{O}$, a snake (o;fij) asp $(\mathrm{o} ; \chi \varepsilon v \tau \rho \alpha) / \Sigma$, a snail (saligka,ri). The last one accompanies the last letter of his name, as an emblem of humility of the martyr metropolitan's entire life.

It was only the snail that was chosen as a blazon of Saint Anthim's, in spite of the fact that in Old Testament dietary laws it had all the features of an unclean living creature. However, even though recent translations of the Bible mentions the snail as a creature which must be avoided, in fact it refers to a species of lizard'; the excerpt from Lev. 11.30 counts five more unclean animals for the Orthodox Jew, but their identity is ambiguous. In the Jewish Bible the snail is appears only once and in

27 Vicenţiu OBOROCEANu, "Aşezământul Sfântul Antim şi faptele iubirii milostive", in vol. Sfânta Mănăstire Antim, Istorie, spiritualitate şi cultură, 1713-2013, Bucureşti, Basilica, 2013, p. 38.

28 "Melc, melc / Codobelc / Scoate coarne boureşti..." or "Melc, melc / Codobelc / Scoate coarne boiereşti..." at Sextil PuȘCARIU, "Bourul şi zimbrul - puţină filologie", in Carpaţi, no. 12/1937, p. 324. 
Septuaginta it is not mentioned at all.

Saint Anthim not only chose the snail as his emblem, but also released it from its link with the earth, uplifting him to the heavenly rest. It may seem odd to assert that the snail could rest not only glued to the ground, in a stable horizontal position, but also in a vertical position. In an aesthetic reading, the slant line incline, by definintion, being undecided, always conveys the feeling of a certain instability, as it can always change its position, by tilting slightly in a direction or anoher. By contrast, a vertical line through its firm direction may be seen as a slant one which came to rest. At first sight, if we were to consider the horizontal and vertical line, the former suggests a state of stillness, as it has defeated any graviational tension and fully rests at the moment. But a spiritual look doesn't see the earthly rest but the heavenly one, and the latter cannot be achieved by coming to a halt but by detaching from the earthly matters and climbing towards the heavenly ones.

Considered to be Saint Anthim's token, who carved himself in the stone decorated frame "the snail, the ray and the star non-verbally tell that the Snail stands for Anthim, who like a snail carries within himself all the gifts received through a ray from God represented by the star; through the same ray he sends them back as a present to the Same God - the Source"29. The Snail, seen as a symbol of the world, "hints at its laws and obstacles. His home, built in a spiral, shows the evolution of creation from the first moment to its full manifestation. The tentacles stretching out and retreating symbolize death and life. Its body with its slow rythm and unwinding, the hardship of climbing, the fear of external attacks, its caution, its obedience, but also its perseverence, all these are included in the snail's wisdom" 30 , as one that cannot surpass its status of a humble ignored creature always in danger.

In the grey mass of stone, "Anthim's emblem often goes unnoticed. In the colours of his Will it is discernible but equally misunderstood. The scholar wanted to tell that, as slow as a snail, with the snail's scanty means

${ }^{29}$ Sofian BoGHIU, Sfântul Antim Ivireanul şi Mănăstirea Tuturor Sfinţilor, Bucureşti, Bizantină, 2005, p. 13.

${ }^{30}$ Virgil CÂNDEA, "Melcul, raza şi steaua", in vol. Sfântul Antim Ivireanul şi Mănăstirea Tuturor Sfintilor, p. 171. 
he tried all his life marked by hardship and noble efforts to reach the light" ${ }^{\text {"11 }}$. Thus, the Metropolitan martyr coming from a little known place and ending as well in an unknown place advanced throughout his life, diligently and painstakingly by hard work, perseverence and slowness in order to reach his goals, offering priceless works of art and cultural monuments which have survived until today and identifying himself with the snail, whose example of prudence and tenacity had followed his entire life; it is for all these reasons that the snail may be considered a true icon/blazon of Saint Anthim the Iberian.

\section{References}

1. Antim IVIREAnUl, Opere, Gabriel ŞTREMPEL (ed.), București, Minerva, 1972.

2. BIANU, I. / HODOŞ, Nerva, Bibliografia românească veche, tomul I (1508-1716), Bucuresci, Stabilimentul Grafic V C Socec, 1903.

3. BoGHIU, Sofian, Sfântul Antim Ivireanul şi Mănăstirea Tuturor Sfinţilor, Bucureşti, Bizantină, 2005.

4. Cernovodeanu, Dan, "Heraldica bisericească în Țările Române", in Biserica Ortodoxă Română, no. 7-8/1975.

5. Cernovodeanu, Dan, Ştiinţa şi arta heraldică în România, Bucureşti, Editura ştiinţifică şi enciclopedică, 1977.

6. Del ChIARO, Anton-Maria, Revolutiile Valahiei (according to the reedited text published by N. Iorga), in Romanian by S. Cris-Cristian, Iaşi, Viaţa Românească, 1929.

7. GHENADIE Craiovenu, Testamentul Mitropolitului Antim Iverenu, in Biserica Ortodoxă Română, no. 3/1885.

8. DOGARU, Maria, "Antim Ivireanul et l'art héraldique de la Valachie", in Revue d'études sud-est européenes, no. 2/1976.

9. IORGA, Nicolae, Istoria literaturii româneşti, Vol. II, Bucureşti, Editura librăriei Pavel Suru, 1926.

10. OBOROCEANU, Vicenţiu, "Așezământul Sfântul Antim şi faptele iubirii milostive", in vol. Sfânta Mănăstire Antim, Istorie, spiritualitate şi cultură, 1713-2013, Bucureşti, Basilica, 2013.

11. PușCARIU, Sextil, "Bourul şi zimbrul - puțină filologie", in Carpaţi, no.

${ }^{31}$ V. CÂNDEA, "Melcul, raza şi steaua”, p. 171. 
12/1937.

12. Sacerdoțeanu, Aurelian, "Sigiliile Mitropolitului Antim Ivireanul", in Mitropolia Olteniei, no. 9-10/1966.

13. SACERDOȚEANU, Aurelian, "Antim Ivireanul, arhivist, bibliotecar şi topograf”, în Glasul Bisericii, no. 9-10/1963.

14. ŞERBĂNESCU, Nicolae, "Antim Ivireanul tipograf”, in Biserica Ortodoxă Română, no. 8-9/1956.

15. ŞTREMPEL, Gabriel, Catalogul manuscriselor româneşti, vol. III, B.A.R. 3101-4413, Bucureşti, Editura Ştiinţifică şi enciclopedică, 1987.

16. VELCULESCU, Cătălina / STĂNCULESCU, Ileana, "Animale între numere şi flori", in Maria Magdalena Székely (ed.), Lumea animalelor, realităţi, reprezentări, simboluri, Iaşi, Editura Universităţii “Alexandru Ioan Cuza", 2012.

\section{Web sources:}

17. http://armorial.library.utoronto.ca/sites/default/Brief-heraldicguide.doc.pdf.

18. http://www.cimec.ro/carte/delchiaro/RevolutiileValahiei.pdf.

19. https://huntingforsnails.wordpress.com/category/heraldry/

\section{List of illustration and their sources:}

1. Fig. 1: The Portal of the The Main Church of the Venerable Monastery of All Saints (personal archive).

2. Fig. 2: The Settlement of the Venerable Monastery of All Saints, in vol. Sofian BoGHIU, Sfântul Antim Ivireanul şi Mănăstirea Tuturor Sfinţilor.

3. Fig. 3: The Settlement (detail).

4. Fig. 4. Heraldic Symbol: Snail; http://www.familytreesandcrests.com/ heraldry-symbols-examples/heraldry-snail.htm.

5. Fig. 5: The bottom side of the votive inscription, detail (personal archive). 


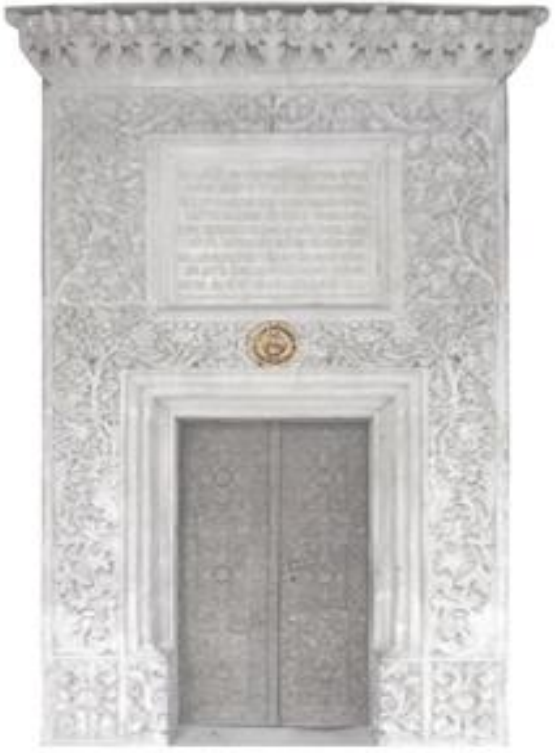

Fig. 1: The Portal of the The Main Church of the Venerable Monastery of All Saints

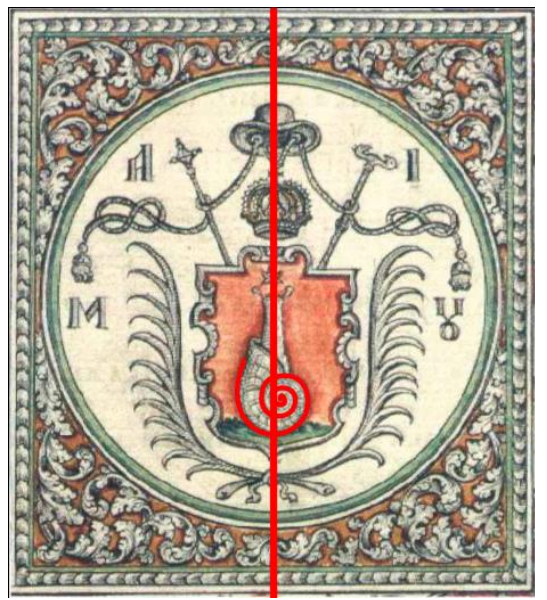

Fig. 3: The Settlement (detail)

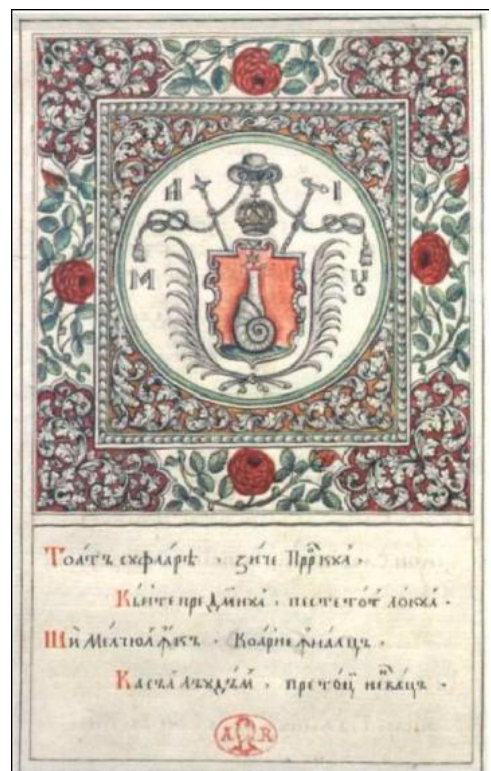

Fig. 2: The Settlement of the

Venerable Monastery of All Saints
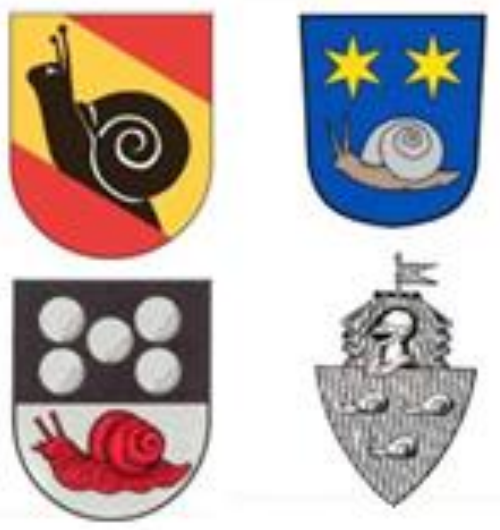

Fig. 4: Heraldic Symbol - Snail 


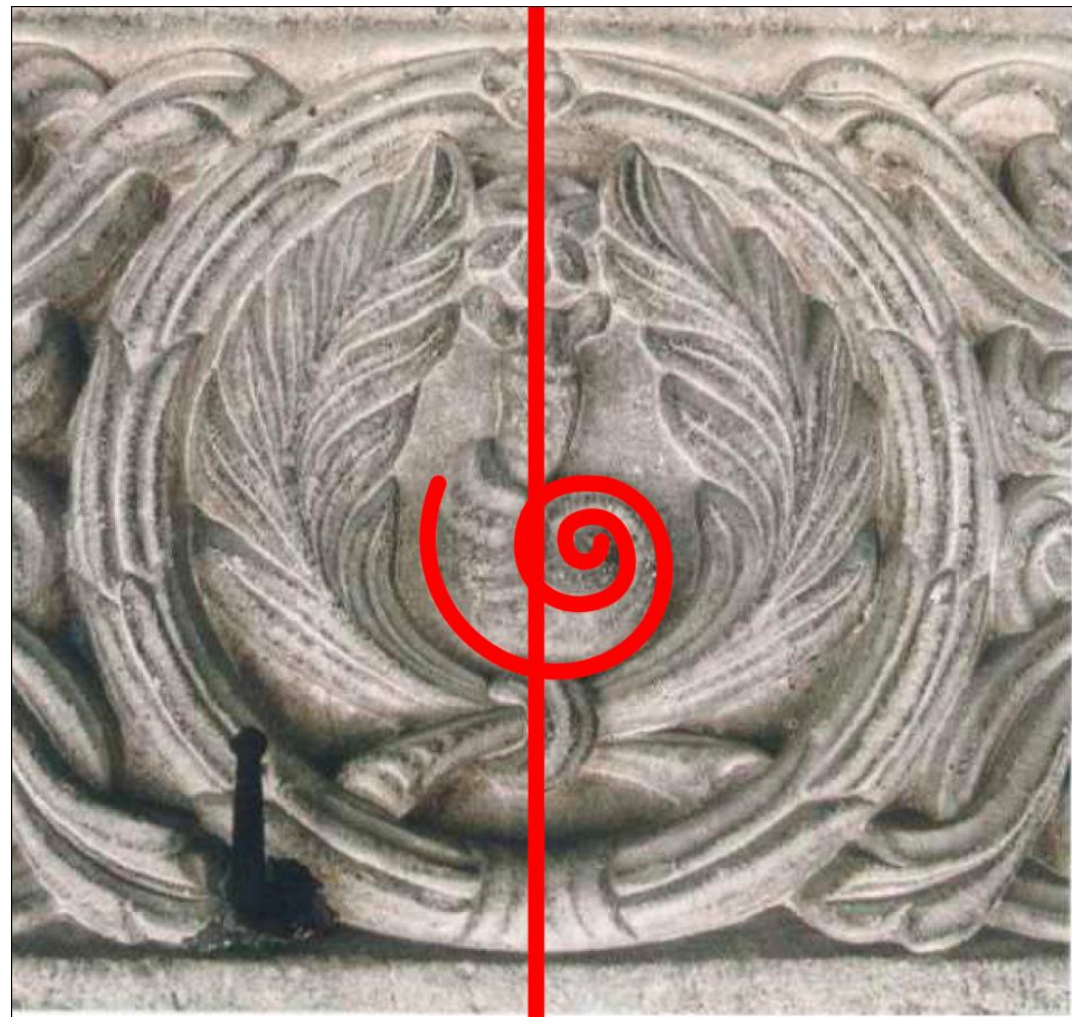

Fig. 5: The bottom side of the votive inscription, detail 